\title{
ЕФЕКТИВНІСТЬ КОМБІНОВАНОЇ ПОСЛІДОВНОї ТЕРАПІї АКТИНІЧНОГО КЕРАТОЗУ
}

\author{
๑Т. В. Святенко ', В. С. Глушок², Т. С. Шкробот ${ }^{3}$
}

'ДЗ «Дніпропетровська медична академія МОз України»

${ }^{2}$ Тернопільський начіональний медичний університет імені І. Я. Горбачевського мОз України

${ }^{3}$ КНП «Тернопільський обласний клінічний шкірно-венерологічний диспансер»

РЕзЮМЕ. Мета роботи - оцінити ефективність використання комбінованої послідовної терапії актинічного кератозу (АК) шляхом порівняння з результатами терапевтичної ефективності монотерапії.

Матеріал і методи. Розроблено триетапний алгоритм комбінованої терапії, спрямованої на послідовне видалення ділянок атипових проліфератів кератиноцитів, на зниження васкуляризації у наявних осередках АК і у потенційно можливих нових осередках на прилеглих ділянках шкіри, а також на покращення стану фотоушкодженої шкіри.

Під спостереженням перебували 90 пацієнтів з АК, яких було рандомізовано у дві групи. Пацієнти 1-ої групи (58 осіб) отримували комбіновану терапію згідно з розробленою методикою, пацієнтам 2-ої групи (32 особи) було проведено лише кріодеструкцію рідким азотом.

Результати та висновки. На основі проведеного аналізу скарг і клінічних даних у пацієнтів до і після лікування, доведено, що комбінована терапія забезпечує кращі клінічні й косметичні ефекти, порівняно з монотерапією. Висока терапевтична ефективність, добра переносимість, малоінвазивність процедур, доступність, зручність застосування дозволяють рекомендувати цю методику для лікування хворих на АК в Україні.

КЛючОВІ СЛОВА: актинічний кератоз; IPL; кріодеструкція; комбінована терапія.

Вступ. Лікування актинічного кератозу (АК) залишається актуальною проблемою в дерматології, оскільки методи, які на сьогодні застосовуються, $\epsilon$ недостатньо ефективними; немає єдиних рекомендацій і клінічного протоколу діагностики та лікування АК в Україні. Пошук більш ефективних методик лікування пояснюється клінічною значущістю AK i, в першу чергу, можливістю його трансформації у плоскоклітинний рак шкіри (ПКРШ).

Вибираючи з численних методів, які тривалий час застосовуються у практиці в різних країнах світу для лікування AK, ми керувались даними груп експертів про те, що ефективність методик слід оцінювати щонайменше за трьома показниками: ступенем розрішення вогнищ АК, частотою виникнення рецидивів, профілем побічної дії. При формуванні терапевтичної стратегії для комбінованого лікування, крім вищезазначених показників, ми також враховували механізм дії кожного методу, прогнозовану тривалість курсу лікування, вартість процедур, доступність для пацієнтів, їх індивідуальні потреби, від яких залежить прихильність (комплаєнтність) пацієнтів до лікування [9-15]. Патогенетичне обґрунтування запропонованого комбінованого лікування базувалось на даних літератури і результатах власних патоморфологічних і імуногістохімічних (ІГХ) досліджень, які підтверджують високий проліферативний потенціал у вогнищах АК, в тому числі за рахунок судинного компонента, який завжди демонструє стан трофіки новоутворення і можливості метастазування $[1,3,6,9,16]$.

Традиційною методикою, яка найчастіше застосовується для лікування АК, $\epsilon$ кріодеструкція вогнищ, тому було розглянуто її використання в комбінованій терапії цього захворювання. Перевагами методики $\epsilon$ доступність, простота, низька потреба в анестезії. Недоліки - виникнення болю під час виконання процедури і деякий час після неї, виникнення побічних ефектів після лікування: утворення міхурів або ерозій, часте формування косметичних дефектів - депігментацій і рубців $[5$, $8,11,13,14]$.

При визначенні тривалості кріодеструкції у комбінованій терапії пацієнтів з АК ми керувалися даними літератури про те, що тривалість кріовпливу на вогнища тісно пов'язана як із ступенем розрішення патологічно змінених ділянок шкіри, уражених АК, так і з вираженістю таких побічних явищ, як депігментація і рубцювання. Так, при заморожуванні вогнища і 1 мм шкіри навколо менше 5 с, повна деструкція $\epsilon$ очікуваною лише у 39 \% випадків, при збільшенні тривалості заморожування від 6 до 20 с - у 69 \%, а при заморожуванні довше 20 с, відповідно у 83 \% [5, 7, 8, 14, 15]. Емпірично було визначено оптимальну тривалість заморожування у комбінованій терапії в інтервалі 10-15 с, з розрахунком на максимальний позитивний ефект і мінімальні побічні впливи. Оскільки вогнища з вираженим гіперкератозом потребують більш тривалого заморожування, для відшарування гіперкератотичних нашарувань застосували $5 \%$ саліцилову мазь напередодні кріотерапії.

Серед останніх сучасних методів, які знайшли застосування в лікуванні AK, нас зацікавила IPLтерапія. Дані про спроби використання цієї методики в лікуванні АК з'явились порівняно недавно, 
Огляди літератури, оригінальні дослідження, погляд на проблему, випадок з практики, короткі повідомлення

а перші отримані результати дозволили припустити, що IPL може бути ефективною як при самостійному використанні, так і в комбінації з іншими методами. Важливими є безпечність цих процедур, здатність запобігати рубцюванню, викликати оклюзію стінок патологічних судин шляхом фотокоагуляції при збереженні цілісності і неушкодженні епідермісу. Під час процедури здійснюється вплив короткочасними світловими спалахами

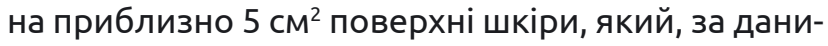
ми літератури, позитивно діє на процес регенерації фотоушкодженої шкіри, що має місце при АК $[4,12,14,17]$.

З урахуванням вищезазначеного було розроблено триетапний алгоритм комбінованої терапії, спрямований на послідовне видалення ділянок атипових проліфератів кератиноцитів, на зниження васкуляризації у наявних осередках АК і у потенційно можливих нових, ще невидимих, утвореннях на прилеглих ділянках шкіри, а також на покращення стану фотоушкодженої шкіри, на якій можуть виникати і прогресувати нові осередки АК. Видалення проводили шляхом попереднього нанесення кератолітичного засобу - 5 \% саліцилової мазі двічі щодня впродовж 5-7 днів до відшарування лусочок і кірочок з наступними сеансами IPL (з довжиною хвилі 560-1200 нм, імпульсом 2226 Дж/см²) № 3-5 у режимі, що відповідає фототипу шкіри пацієнта, 1 раз на 7-10 днів, залежно від вираженості місцевої реакції в зоні впливу. Наступним у комбінованій терапії було проведення кріодеструкції спреєм рідкого азоту тривалістю 10-15 с одноразово, за допомогою Brymill's Cry-Ac®. Курс лікування тривав 1-2 місяці $[2,4]$.

Мета роботи - оцінити ефективність використання комбінованої послідовної терапії АК шляхом порівняння з результатами терапевтичної ефективності монотерапії (кріодеструкція рідким азотом).

Матеріал і методи дослідження. Під спостереженням перебувало 90 пацієнтів, у яких було верифіковано АК клінічно і методом дерматоскопії.

Усіх пацієнтів було рандомізовано у дві групи. Пацієнти 1-ої групи (58 осіб), отримували комбіновану терапію згідно з розробленою методикою, пацієнтам 2-ї групи (32 особи), було проведено лише кріодеструкцію рідким азотом (методика монотерапії). Обидві терапевтичні групи були статистично зіставними $(p>0,05)$ за віком, статтю і місцем проживання пацієнтів, а також за клінічними формами і ступенем тяжкості АК, фототипами шкіри (табл. 1).

Таблиця 1. Порівняння терапевтичних груп хворих на актинічний кератоз за ступенем тяжкості, фототипом шкіри і клінічним варіантом захворювання, абс. (\%)

\begin{tabular}{|c|c|c|c|c|}
\hline \multicolumn{2}{|c|}{ Показник } & $\begin{array}{c}\text { Перша група } \\
\text { (комбінована терапія) } \\
(\mathrm{n}=58)\end{array}$ & $\begin{array}{c}\text { Друга група } \\
\text { (монотерапія) } \\
\text { (n=32) }\end{array}$ & $\begin{array}{c}\text { Значимість різниці } \\
\text { між групами }\end{array}$ \\
\hline \multirow[t]{3}{*}{ Ступінь тяжкості АК } & 1 & $12(20,7 \%)$ & $11(34,4 \%)$ & 0,207 \\
\hline & II & $29(50,0 \%)$ & $12(37,5 \%)$ & 0,278 \\
\hline & III & $17(29,3 \%)$ & $9(28,1 \%)$ & 1,00 \\
\hline \multirow{3}{*}{ Фототип шкіри } & 1 & $1(1,7 \%)$ & $2(6,3 \%)$ & 0,287 \\
\hline & II & $42(72,4 \%)$ & $24(75,0 \%)$ & 1,00 \\
\hline & III & $15(25,9 \%)$ & $6(18,8 \%)$ & 0,604 \\
\hline \multirow[t]{3}{*}{ Клінічний варіант АК } & Пігментний & $17(29,3 \%)$ & $6(18,8 \%)$ & 0,321 \\
\hline & Проліферативний & $35(60,3 \%)$ & $24(75,0 \%)$ & 0,175 \\
\hline & Гіпертрофічний & $5(8,6 \%)$ & $2(6,3 \%)$ & 1,00 \\
\hline
\end{tabular}

Примітка. Рівень значимості різниці показників між групами (р) вказаний за ТКФ.

Результати й обговорення. Результати проведеного лікування простежені в усіх пацієнтів обох груп та ґрунтувались на даних розширеного аналізу і порівняльної оцінки всієї суб'єктивної та об'єктивної симптоматики АК за оцінкою клінічних проявів через 3 місяці і 1 рік від початку лікування.

Динаміка регресу клінічних проявів захворювання у пацієнтів, котрим проведено монотерапію

Аналіз динаміки скарг пацієнтів показав, що через 3 місяці після проведення кріодеструкції вірогідно $(p<0,05)$ зменшився відсоток пацієнтів, які мали скарги на свербіж, сухість, почервоніння і шорсткість шкіри (табл. 2) і жоден з пацієнтів не скаржився на наявність кірочок, кровоточивість.

Через 12 місяців жоден з пацієнтів не скаржився на сухість шкіри і кровоточивість, лише двох пацієнтів (6,3%) турбувало почервоніння, тоді як до початку лікування цю скаргу мали 27 (84,4 \%) пацієнтів. На свербіж і шорсткість скаржилися відповідно 7 (21,9\%) і 9 (28,1\%). Через 12 місяців у $9(28,1 \%)$ пацієнтів знову з'явилися скарги на наявність кірочок на шкірі.

В усіх 32 пацієнтів поверхня шкіри до проведення монотерапії не була гладкою. Застосуванням методу монотерапії досягнуто часткової позитивної 
Огляди літератури, оригінальні дослідження, погляд на проблему, випадок з практики, короткі повідомлення

Таблиця 2. Динаміка скарг хворих на актинічний кератоз до і після проведення монотерапії, абс. (\%)

\begin{tabular}{|l|c|c|c|}
\hline \multicolumn{1}{|c|}{ Скарга } & До початку терапії & Через 3 місяці & Через 12 місяців \\
\hline Свербіж & $13(40,6 \%)$ & $6(18,8 \%)^{*}$ & $7(21,9 \%)$ \\
\hline Сухість & $16(50,0 \%)$ & $6(18,8 \%)^{* *}$ & $-* * *$ \\
\hline Почервоніння & $27(84,4 \%)$ & $6(18,8 \%)^{* * *}$ & $2(6,3 \%)^{* * *}$ \\
\hline Шорсткість & $32(100,0 \%)$ & $15(46,9 \%)^{* * *}$ & $9(28,1 \%)^{* * *}$ \\
\hline Наявність кірочок & $18(56,3 \%)$ & $-* * *$ & $9(28,1 \%)^{*}$ \\
\hline Кровоточивість & $3(9,4 \%)$ & - & - \\
\hline
\end{tabular}

Примітка. ${ }^{*}-p<0,05 ;{ }^{* *}-p<0,01 ; * * *-p<0,001$ порівняно з початковим рівнем

динаміки (табл. 3): гладкість шкіри відмічено у 40,6 \% пацієнтів через 3 місяці і у 59,4 \% пацієнтів через 12 місяців. Злегка шорсткою була шкіра у 15 (46,9 \%) пацієнтів після терапії через 3 місяці, тоді як до лікування її так оцінювали лише 12 (37,5 \%) пацієнтів. Через 12 місяців відсоток пацієнтів, котрі мали таку оцінку поверхні шкіри, зменшився до 9,4 \% $(p<0,01)$. Якщо через 3 місяці значимо змен- шилась частка пацієнтів з шорсткою шкірою (з 59,4 \% до 12,5 \%), то через 12 місяців їх кількість збільшилася до 25,0 \%. Як колючу при пальпації до лікування було оцінено поверхню шкіри у 8 (25,0\%) пацієнтів, через 3 місяці такої характеристики шкіра не мала у жодного пацієнта, а через 12 місяців у 2 (6,3 \%) пацієнтів шкіра знову стала колючою у вогнищах ураження актинічним кератозом.

Таблиця 3. Динаміка характеристик поверхні шкіри у хворих на актинічний кератоз після проведення монотерапії, абс. (\%)

\begin{tabular}{|l|c|c|c|}
\hline $\begin{array}{c}\text { Характеристика поверхні } \\
\text { шкіри }\end{array}$ & До початку терапії & Через 3 місяці & Через 12 місяців \\
\hline Гладка & $0(0,0 \%)$ & $13(40,6 \%)^{* * *}$ & $19(59,4 \%)^{* * *}$ \\
\hline Злегка шорстка & $12(37,5 \%)$ & $15(46,9 \%)$ & $3(9,4 \%)^{* *}$ \\
\hline Шорстка & $19(59,4 \%)$ & $4(12,5 \%)^{* * *}$ & $8(25,0 \%)^{* *}$ \\
\hline Колюча & $8(25,0 \%)$ & $-* *$ & $2(6,3 \%)^{*}$ \\
\hline
\end{tabular}

Примітка. * - p<0,05; ** - p<0,01; *** - p<0,001 порівняно з початковим рівнем

Ефективність проведеної монотерапії також оцінювали за ступенем очищення шкіри від вогнищ ураження АК. Через 3 місяці повне очищення спостерігали у 12 (37,5\%) пацієнтів, часткове -у 20 (62,5\%). Рецидивних уражень через 3 місяці не було виявлено у жодного з пацієнтів. Через 12 місяців повне очищення відбулося у 18 (56,3 \%) пацієнтів, рецидивні ураження з'явились у 14 (43,8 \%) пацієнтів.

Важливим показником ефективності терапії і одночасно прихильності пацієнтів до цієї методики $\epsilon$ отриманий косметичний ефект після проведення лікування. Без косметичних дефектів через 3 місяці після проведеної кріодеструкції було 40,6 \% пацієнтів; через 12 місяців їх відсоток склав 50 (16 пацієнтів). У жодного пацієнта через 3 місяці і через 12 місяців не було виявлено рубців і атрофії.

Гіпопігментацію було виявлено у 25,0 \% пацієнтів через 3 місяці і у 21,9 \% пацієнтів через 12 місяців після проведеного лікування. Гіперпігментація спостерігалась у меншого відсотка пацієнтів: у 18,8 \% через 3 місяці і у 6,3 \% через 12 місяців. Ще меншою була частка пацієнтів з диспігментацією: 15,6 \% через 3 місяці і 3,1 \% через 12 місяців. Отримані косметичні результати після проведення кріо- деструкції рідким азотом у досліджуваних пацієнтів оцінили як задовільні.

Параметри безпеки проведеної монотерапії оцінювали через 3 міс. за оцінкою переносимості процедури пацієнтами.

Доброю була переносимість процедури у 24 (75,0 \%) пацієнтів, задовільною - у 8 (25,0 \%). Відсутність болю відмітили 3 (9,4 \%) пацієнти, 17 $(53,1 \%)$ оцінили його як незначно виражений (1 бал), 12 (37,5 \%) - як помірний (2 бали).

Динаміка регресу клінічних проявів захворювання після проведеної комбінованої терапіï

Скарги пацієнтів основної групи, котрим проведено лікування за методикою комбінованої терапії, теж оцінювали через 3 і 12 місяців після завершення лікування. Дані, наведені у таблиці 4, демонструють відсутність у пацієнтів через 3 і 12 міс. скарг на сухість шкіри і кровоточивість, значне зменшення частки пацієнтів із скаргами на почервоніння: з 67,2 \% до 3,4 \% через 3 місяці і до 1,7 \% через 12 місяців $(p<0,001)$, відсутність у пацієнтів скарг на наявність кірочок через 3 місяці після проведеної терапії і відновлення цієї скарги через 12 місяців у 4 (6,9 \%) пацієнтів. 
Огляди літератури, оригінальні дослідження, погляд на проблему, випадок з практики, короткі повідомлення Таблиця 4. Динаміка скарг хворих на актинічний кератоз, котрим проведено лікування методом комбінованої терапії

\begin{tabular}{|l|c|c|c|}
\hline \multicolumn{1}{|c|}{ Скарга } & До початку терапії & Через 3 місяці & Через 12 місяців \\
\hline Свербіж & $21(36,2 \%)$ & $11(19,0 \%)^{*}$ & $8(13,8 \%)^{* *}$ \\
\hline Сухість & $25(43,1 \%)$ & $-* * *$ & $-* * *$ \\
\hline Почервоніння & $39(67,2 \%)$ & $2(3,4 \%)^{* * *}$ & $1(1,7 \%)^{* * *}$ \\
\hline Шорсткість & $58(100,0 \%)$ & $11(19,0 \%)^{* * *}$ & $10(17,2 \%)^{* * *}$ \\
\hline Наявність кірочок & $41(70,7 \%)$ & $-* * *$ & $4(6,9 \%)^{* * *}$ \\
\hline Кровоточивість & $3(5,2 \%)$ & - & - \\
\hline
\end{tabular}

Примітка. * $-p<0,05 ; * *-p<0,01 ; * * *-p<0,001$ порівняно з початковим рівнем

Вірогідно зменшилось число скарг на свербіж: з 36,2 \% до 19,0 \% через 3 місяці $(p<0,05)$ і до $13,8 \%$ через 12 місяців ( $<<0,01)$. Шорсткість шкіри в місцях ураження АК, яку було виявлено в усіх хворих до початку терапії, через 3 і 12 місяців після проведеного лікування виявлялась лише у $19,0 \%$ і $17,2 \%$ пацієнтів $(p<0,001)$.

Дані, наведені в таблиці 5 демонструють переконливу позитивну динаміку характеристик поверхні ураженої шкіри. Так, поверхня шкіри через
3 місяці після проведеної комбінованої терапії стала гладкою у 77,6 \% (до початку лікування була лише у $1,7 \%$ ), а через 12 місяців - у 79,3\% пацієнтів $(p<0,001)$. Значно зменшилась частка пацієнтів із колючою поверхнею шкіри: з 22,4 \% до 1,7 \% через 3 і 12 місяців $(p<0,001)$. Число пацієнтів 3 шорсткою шкірою майже в 10 разів зменшилось через 3 місяці після проведеної комбінованої терапії, однак через 12 місяців шорсткість знову визначалась у 19,0 \% пацієнтів.

Таблиця 5. Динаміка характеристик поверхні шкіри у хворих на актинічний кератоз, котрі отримали лікування методом комбінованої терапії

\begin{tabular}{|l|c|c|c|}
\hline \multicolumn{1}{|c|}{$\begin{array}{c}\text { Характеристика поверхні } \\
\text { шкіри }\end{array}$} & До початку лікування & Через 3 місяці & Через 12 місяців \\
\hline Гладка & $1(1,7 \%)$ & $45(77,6 \%)^{* * *}$ & $46(79,3 \%)^{* * *}$ \\
\hline Злегка шорстка & $14(24,1 \%)$ & $9(15,5 \%)$ & $-* * *$ \\
\hline Шорстка & $39(67,2 \%)$ & $4(6,9 \%)^{* * *}$ & $11(19,0 \%)^{* * *}$ \\
\hline Колюча & $13(22,4 \%)$ & $1(1,7 \%)^{* * *}$ & $1(1,7 \%)^{* * *}$ \\
\hline
\end{tabular}

Примітка. * - $<<0,05 ; * *-p<0,01 ; * * *-p<0,001$ порівняно з початковим рівнем

Загальною лікарською оцінкою ступеня очищення шкіри від вогнищ АК на тлі комбінованої терапії встановлено, що через 3 місяці повного очищення шкіри досягнуто у 49 (84,5 \%) пацієнтів, часткового - у 9 (15,5\%); рецидивних уражень не виявлено. Через 12 місяців повне очищення було у $44(75,9 \%)$, рецидивні ураження виявлено у 13 (22,4\%) пацієнтів.

Позитивний косметичний результат отримано у $67,2 \%$ пацієнтів через 3 місяці і у 87,9 \% через 12 місяців після проведення комбінованої терапії. Частки пацієнтів з гіпо-, гіпер- і диспігментаціями були доволі малими через 3 місяці і ще меншими через 12 місяців. У 1 пацієнта виявлено поверхневу атрофію у вогнищі АК, що, ймовірно, пояснюється індивідуальними особливостями шкіри.

Добра переносимість процедур кріодеструкції відзначена у $44(75,9 \%)$ пацієнтів, задовільна у 14 (24,1\%). Біль був відсутнім у 10 (17,2 \%) паці$\epsilon$ нтів, 31 (53,4 \%) оцінили його як незначно виражений, 17 (29,3 \%) як помірний.
Результати проведеної порівняльної оцінки основних параметрів ефективності комбінованої і монотерапії у пацієнтів з АK

Як видно з даних таблиці 6, на тлі порівнянних вихідних даних до початку терапії в обох групах ( $>>0,05$ між групами при усіх порівняннях) після проведення комбінованої терапії через 3 і 12 місяців скарг не було у більшого відсотка пацієнтів.

Результати порівняльного аналізу характеристик поверхні шкіри у вогнищах ураження також підтверджують більшу ефективність комбінованої терапії (табл. 7). Так, через 3 місяці після комбінованої терапії поверхня шкіри була гладкою у 77,6 \% пацієнтів, через 12 місяців - у 79,3\% пацієнтів. У пацієнтів, які отримали монотерапію, через 3 місяці гладку поверхню шкіри мали 40,6 \% $(p<0,001)$, через 12 місяців - 59,4 \% $(p=0,043)$.

Аналіз даних, наведениху таблиці 8, демонструє більшу ефективність комбінованої терапії за показниками повного очищення шкіри і частотою виникнення рецидивів через 3 і 12 місяців після лікування. 
Огляди літератури, оригінальні дослідження, погляд на проблему, випадок з практики, короткі повідомлення

Таблиця 6. Показники динаміки частоти відсутності скарг у хворих на актинічний кератоз після проведення лікування різними методиками, \%

\begin{tabular}{|c|c|c|c|c|c|c|}
\hline \multirow{2}{*}{ Скарги } & \multicolumn{3}{|c|}{$\begin{array}{c}\text { Перша група (комбінована терапія) } \\
(\mathrm{n}=58)\end{array}$} & \multicolumn{3}{|c|}{$\begin{array}{c}\text { Друга група (монотерапія) } \\
\text { (n=32) }\end{array}$} \\
\hline & $\begin{array}{c}\text { до початку } \\
\text { терапії }\end{array}$ & $\begin{array}{c}\text { через } \\
3 \text { місяці }\end{array}$ & $\begin{array}{c}\text { через } \\
12 \text { місяців }\end{array}$ & $\begin{array}{c}\text { до початку } \\
\text { терапії }\end{array}$ & $\begin{array}{c}\text { через } \\
3 \text { місяці }\end{array}$ & $\begin{array}{c}\text { через } \\
12 \text { місяців }\end{array}$ \\
\hline Свербіж & 63,8 & 81,0 & 86,2 & 59,4 & 81,3 & 78,1 \\
\hline Сухість шкіри & 56,9 & 100 & 100 & 50,0 & 81,3 ** & 100 \\
\hline Почервоніння & 32,8 & 96,6 & 98,3 & 15,6 & 81,3 * & 93,8 \\
\hline Шорсткість & 0,0 & 81,0 & 82,8 & 0,0 & $53,1 * *$ & 71,9 \\
\hline Наявність кірочок & 29,3 & 100 & 93,1 & 43,8 & 100 & 71,9 * \\
\hline Кровоточивість & 94,8 & 100 & 100 & 90,6 & 100 & 100 \\
\hline
\end{tabular}

Примітка. * - p<0,05; ** - p<0,01 порівняно з відповідним показником у 1-й групі

Таблиця 7. Показники динаміки характеристик поверхні шкіри у хворих на актинічний кератоз після лікування різними методиками, \%

\begin{tabular}{|c|c|c|c|c|c|c|}
\hline \multirow{2}{*}{$\begin{array}{l}\text { Характеристика } \\
\text { поверхні шкіри }\end{array}$} & \multicolumn{3}{|c|}{$\begin{array}{c}\text { Перша група (комбінована терапія) } \\
(n=58)\end{array}$} & \multicolumn{3}{|c|}{$\begin{array}{c}\text { Друга група (монотерапія) } \\
\text { (n=32) }\end{array}$} \\
\hline & $\begin{array}{l}\text { до початку } \\
\text { терапії }\end{array}$ & $\begin{array}{c}\text { через } \\
3 \text { місяці }\end{array}$ & $\begin{array}{c}\text { через } \\
12 \text { місяців }\end{array}$ & $\begin{array}{l}\text { до початку } \\
\text { терапії }\end{array}$ & $\begin{array}{c}\text { через } \\
3 \text { місяці }\end{array}$ & $\begin{array}{c}\text { через } \\
12 \text { місяців }\end{array}$ \\
\hline Гладка & 1,7 & 77,6 & 79,3 & 0,0 & $40,6 * * *$ & 59,4 * \\
\hline Злегка шорстка & 24,1 & 15,5 & - & 37,5 & $46,9 * *$ & 9,4 * \\
\hline Шорстка & 67,2 & 6,9 & 19,0 & 59,4 & 12,5 & 25,0 \\
\hline Колюча & 22,4 & 1,7 & 1,7 & 25,0 & - & 6,3 \\
\hline
\end{tabular}

Примітка. * - p<0,05; ** - p<0,01; ** - p<0,001 порівняно з відповідним показником у 1-й групі.

Таблиця 8. Показники оцінки ступеня очищення шкіри у хворих на актинічний кератоз після проведеного лікування різними методиками, \%

\begin{tabular}{|l|c|c|c|c|}
\hline \multirow{2}{*}{ Ступінь очищення } & \multicolumn{2}{|c|}{$\begin{array}{c}\text { Перша група (комбінована терапія) } \\
(\mathrm{n}=58)\end{array}$} & \multicolumn{2}{c|}{ Друга група (монотерапія) } \\
& \multicolumn{2}{|c|}{$(\mathrm{n=32)}$}
\end{tabular}

Примітка. * - p<0,05; ** - p<0,001 порівняно з відповідним показником у 1-й групі.

Одночасно було проведено аналіз факторів, які, ймовірно, сприяють появі рецидивів. Виявлено, що частіше рецидиви траплялися у пацієнтів з гіпертрофічним клінічним варіантом АК - 71,4 \% (5 з 7 пацієнтів з вказаною формою АК), тоді як у пацієнтів з пігментною формою частота рецидивів складала $26,1 \%$, 3 проліферативною - 27,1 \% (р<0,001 порівняно з гіпертрофічним варіантом). Найвищий показник рецидивування АК виявлено у пацієнтів з III ступенем тяжкості - 69,2 \% (18 з 26 пацієнтів), тоді як при I ступені тяжкості він склав лише 8,7 \% (2 з 23), при II ступені - 17,1 \% (7 з 41 пацієнтів).

Встановлено, що в обох терапевтичних групах частота рецидивів вірогідно не відрізнялась за вищезазначеними показниками тяжкості і клінічного варіанта AK ( $p>0,05$ при усіх порівняннях відповідних показників).
Комбінована терапія АК дозволила отримати кращі косметичні результати, порівняно з монотерапією (рис. 1).

Через 3 місяці відсутність косметичних дефектів відзначена у $67,0 \%$ пацієнтів основної групи і лише у $40,6 \%$ пацієнтів групи порівняння $(p=0,025)$. При пост-лікувальному моніторингу, проведеному через 12 місяців, встановлено збільшення цих показників до 87,9 \% у групі після проведеної комбінованої терапії і до 50,0 \% - після проведення лише кріодеструкції рідким азотом $(p<0,001)$.

Клінічні випадки з результатами проведеної пацієнтам комбінованої послідовної терапії продемонстровані на рисунках 2 і 3.

Висновки. На підставі проведеного аналізу оцінки динаміки скарг і клінічних даних у пацієнтів до і після лікування, доведено, що комбінована 
Огляди літератури, оригінальні дослідження, погляд на проблему, випадок з практики, короткі повідомлення

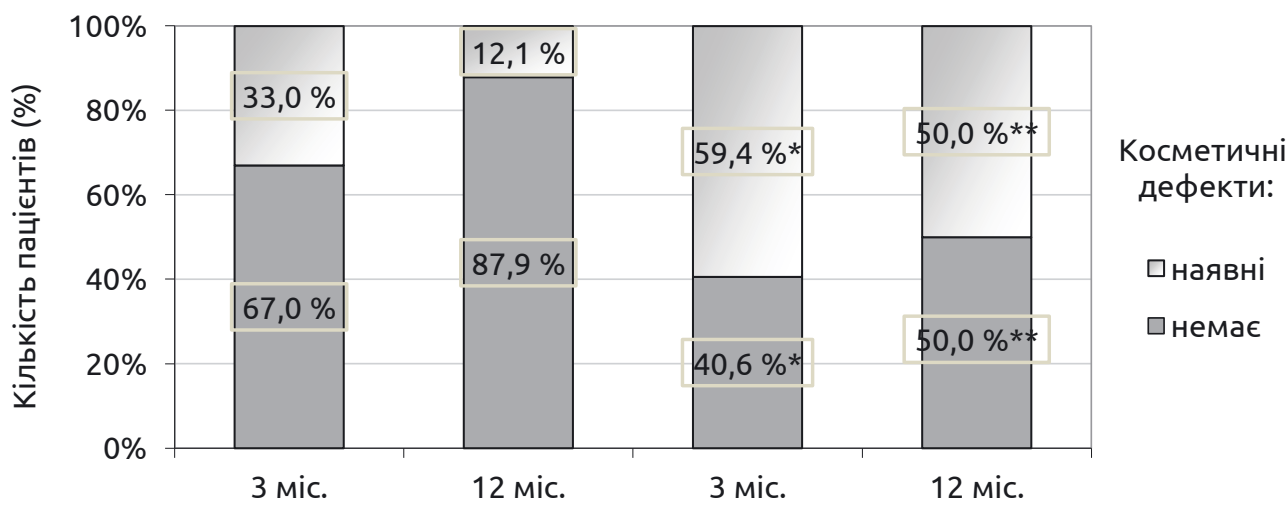

Комбінована терапія

Монотерапія

Примітка. * - p<0,05; ** - p<0,001 порівняно з відповідним показником у групі комбінованої терапії.

Рис. 1. Порівняння частоти виявлення косметичних дефектів у хворих на актинічний кератоз на тлі застосування різних методик лікування.
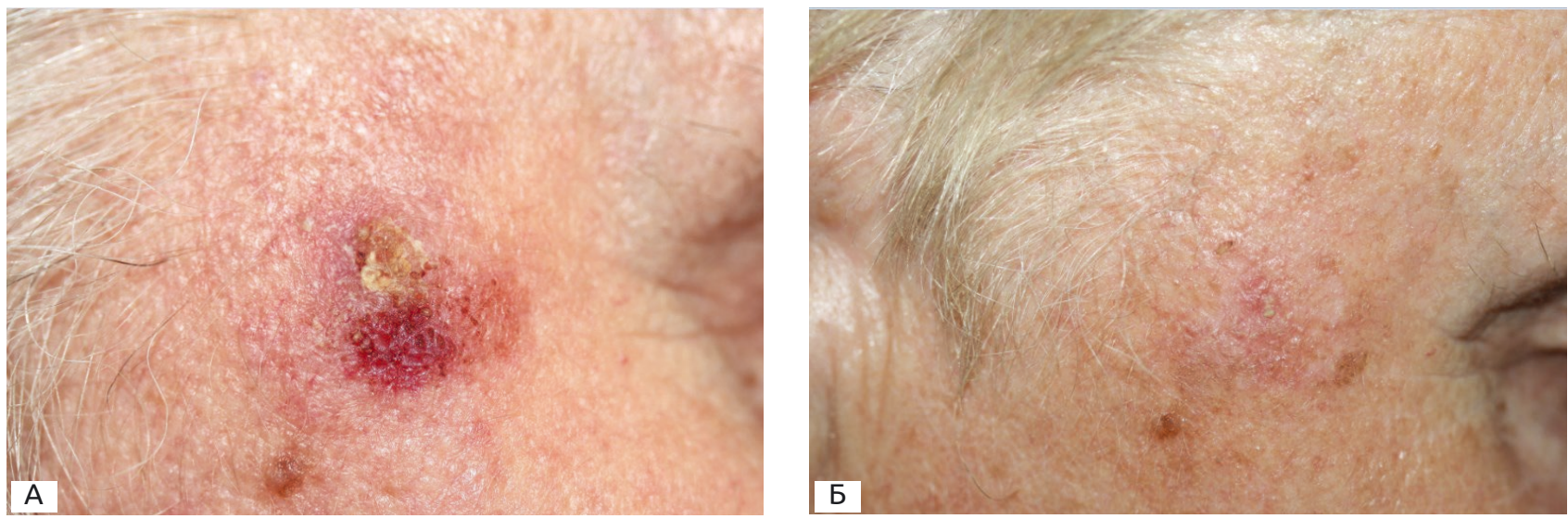

Рис. 2. Актинічний кератоз, проліферативний варіант. А. До лікування. Б. Через 12 місяців після комбінованої терапії.
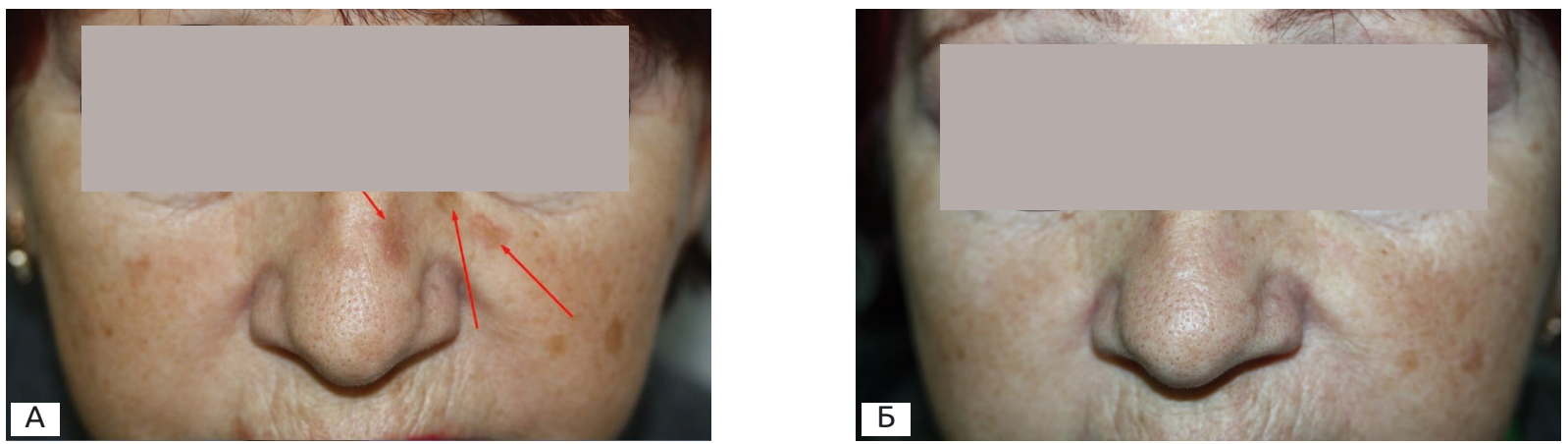

Рис. 3. Актинічний кератоз, пігментний варіант. А. До лікування. Б. Через 12 місяців після комбінованої терапії

послідовна терапія із застосуванням кератолітичного засобу - 5 \% саліцилової мазі, процедур інтенсивного імпульсного світла IPL і кріодеструкції рідким азотом забезпечує кращі клінічні, і косметичні ефекти, порівняно з монотерапією. Висо- ка терапевтична ефективність, добра переносимість, малоінвазивність процедур, доступність, зручність застосування дозволяють рекомендувати цю методику для лікування хворих на АК в Україні. 
Огляди літератури, оригінальні дослідження, погляд на проблему, випадок з практики, короткі повідомлення ЛІТЕРАТУРА

1. Глушок В. С., Святенко Т. В., Шпонька І. І., Пославська О. В. Спосіб діагностики актинічного кератозу: пат. 125617 Україна: МПК (2018.01), GO1N21/00; заявл. 22.01.2018; опубл. 10.05.2018, Бюл. № 9.

2. Глушок В.С. Власний досвід комбінованої послідовної терапії актинічного кератозу / В. С. Глушок, Т. В. Святенко // Дерматологія та венерологія. -2018. - № 1 (79). C. $39-42$.

3. Оцінка стану проліферативної активності та експресії онкомаркеру р53 в зразках актинічного кератозу / В. С. Глушок, Т. В. Святенко, І. С. Шпонька, О. В. Пославська // Морфологія. - 2017. - Т. 11, № 3. - С. 6-12.

4. Святенко Т. В. Комбінована терапія актинічного кератозу з врахуванням морфофенотипування / Т. В. Святенко, В. С. Глушок // Інформаційний лист. - К., 2018. № 31, вип. 2: Дерматологія та венерологія.

5. A consensus approach to improving patient adherence and persistence with topical treatment for actinic keratosis / E. Stockfleth, K. Peris, C. Guillen [et al.] // Int. J. Dermatol. - 2015. - Vol. 54, Iss. 5. - P. 509-515.

6. A prospective randomized exploratory study comparing the efficacy of once-daily topical $0.5 \% 5$-fluorouracil in combination with $10.0 \%$ salicylic acid (5-FU/SA) vs. cryosurgery for the treatment of hyperkeratotic actinic keratosis / J. C. Simon, R. Dominicus, L. Karl [et al.] // J. Eur. Acad. Dermatol. Venereol. - 2015. - Vol. 29, Iss. 5. - P. 881-889.

7. Actinic keratosis clinical practice guidelines: An appraisal of quality / J. S. Kirby, T. Scharnitz, E. V. Seiverling [et al.] // Dermatol. Res. Pract. - 2015. - Vol. 2015. - Article ID 456071.

8. Afsar F. S. Clinical practice trends in cryosurgery: a retrospective study of cutaneous lesions / F. S. Afsar, C. D. Erkan, S. Karaca // Postepy Dermatol. Alergol. - 2015. Vol. 32, Iss. 2. - P. 88-93.

\section{REFERENCES}

1. Hlushok, V.S., Sviatenko, T.V., Shponka, I.I., \& Poslavska O. V. Sposib diahnostyky aktyvnoi keratozu: pat. 125617 Ukraina: MPK (2018.01), GO1N21 / 00; zaiavl. 22.01.2018; opubl. 05.05.2018, Byul. № 9. [Method for the diagnosis of active keratosis: Pat. 125617 Ukraine: IPC (2018.01), GO1N21 / 00; claimed 22.01.2018; publ. 05/05/2018, Bul. No. 9]. [in Ukrainian].

2. Hlushok, V.S., \& Sviatenko, T.V. (2018). Vlasnyi dosvid kombinovanoi poslidovnoi terapii aktynichnoho keratozu [Personal experience of the combined sequential therapy of actinic keratosis]. Dermatolohiia ta venerolohiia - Dermatology and Venereology, 1 (79), 39-42 [in Ukrainian].

3. Hlushok, V.S., Sviatenko, T.V., Shponka, I.S., \& Poslavska, O.V. (2017). Otsinka stanu proliferatyvnoi aktyvnosti ta ekspresii onkomarkeru p53 v zrazkakh aktynichnoho keratozu [Assessment of proliferative activity and p53 tumor marker expression in actinic keratosis specimens]. Morfolohiia-Morphology, 11, 3, 6-12 [in Ukrainian].

4. Sviatenko, T.V., \& Hlushok, V.S. (2018). Kombinovana terapiia aktynichnoho keratozu z vrakhuvanniam morfofenotypuvannia [Combination therapy of actinic keratosis with consideration of morphophenotyping]. Informa-

9. British Association of Dermatologists' guidelines for the care of patients with actinic keratosis 2017 / D. de Berker, J. M. McGregor, M. F. Mohd Mustapa [et al.] // Br. J. Dermatol. - 2017. - Vol. 176, Iss. 1. - P. 20-43.

10. Chaplin S. Topical agents for preventing and treating actinic keratosis / S. Chaplin // Prescriber. - 2016. P. 32-40.

11. Chetty P. Primary care review of actinic keratosis and its therapeutic options: A global perspective / P. Chetty, F. Choi, T. Mitchell // Dermatol. Ther. (Heidelb). - 2015. Vol. 5, Iss. 1. - P. 19-35.

12. Clinical study. Unconventional use of intense pulsed light / D. Piccolo, D. Di Marcantonio, G. Crisman [et al.] // Biomed. Res. Int. - 2014. - Vol. 2014. - Article ID 618206.

13. Community-based practice variations in topical treatment of actinic keratoses / M. Storer, Z. Zhu, M. Sokil [et al.] // JAMA Dermatol. - 2017. - Vol. 153, Iss. 5. P. 468-470.

14. Daylight photodynamic therapy versus cryosurgery for the treatment and prophylaxis of actinic keratoses of the face - protocol of a multicenter, prospective, randomized, controlled, two-armed study / E. Kohl, M. Koller, F. Zeman [et al.] // BMS Dermatol. - 2017. - Vol. 17. - Article ID 29070025.

15. Dodds A. Actinic keratosis: Rationale and management / A. Dodds, A. Chia, S. Shumack // Dermatol. Ther (Heidelb). - 2014. - Vol. 4, Iss. 1. - P. 11-31.

16. Elizabeth E. Uhlenhake Optimal treatment of actinic keratoses / E. Elizabeth // Clin. Interv. Aging. - 2013. Vol. 8. - P. 29-35.

17. Lasers and intense pulsed light (IPL) association with cancerous lesions / C. Ash, G. Town, R. Whittall [et al.] // Lasers Med Sci. - 2017. - Vol. 32, Iss. 8. - P. 1927-1933.

tsiinyy lyst. Dermatolohiia ta venerolohiia - Information Sheet. Dermatology and Venereology, 31, 2 [in Ukrainian].

5. Stockfleth, E., Peris, K., Guillen, C., Cerio, R., BassetSeguin, N., Foley, P., ..., \& Lebwohl, M. (2015). A consensus approach to improving patient adherence and persistence with topical treatment for actinic keratosis. Int. J. Dermatol., $54,5,509-515$.

6. Simon, J.C., Dominicus, R., Karl, L., Rodríguez, R., Willers, C., \& Dirschka, T. (2015). A prospective randomized exploratory study comparing the efficacy of once-daily topical $0.5 \% 5$-fluorouracil in combination with $10.0 \%$ salicylic acid (5-FU/SA) vs. cryosurgery for the treatment of hyperkeratotic actinic keratosis. J. Eur. Acad. Dermatol. Venereol., 29, 5, 881-889.

7. Kirby, J.S., Scharnitz, T., Seiverling, E.V., Ahrns, H, \& Ferguson, S. (2015). Actinic keratosis clinical practice guidelines: An appraisal of quality Dermatol. Res. Pract. Article ID 456071.

8. Afsar, F.S., Erkan, C.D., \& Karaca, S. (2015). Clinical practice trends in cryosurgery: a retrospective study of cutaneous lesions. Postepy Dermatol. Alergol., 32, 2, 88-93.

9. de Berker, D., McGregor, J.M., Mohd Mustapa, M.F., Exton, L.S., \& Hughes, B.R. (2017). British Association of 
Огляди літератури, оригінальні дослідження, погляд на проблему, випадок з практики, короткі повідомлення Dermatologists' guidelines for the care of patients with actinic keratosis 2017. Br. J. Dermatol., 176, 1, 20-43.

10. Chaplin S. (2016). Topical agents for preventing and treating actinic keratosis. Prescriber, 32-40.

11. Chetty, P., Choi, F., \& Mitchell, T. (2015). Рrimary care review of actinic keratosis and its therapeutic options: A global perspective. Dermatol. Ther. (Heidelb), 5, 1, 19-35.

12. Piccolo, D., Marcantonio, D.Di, Crisman, G., Cannarozzo, G., Sannino, M., Chiricozzi, A., \& Chimenti, S. (2014). Clinical study. Unconventional use of intense pulsed Light. Biomed. Res. Int., 2014, Article ID 618206.

13. Storer, M., Zhu, Z., Sokil, M., Ford, M., Neugebauer, R., \& Asgari, M.M. (2017). Community-based practice variations in topical treatment of actinic keratoses. JAMA Dermatol., 153, 5, 468-470.

14. Kohl, E., Koller, M., Zeman, F., Szeimies, R.M., Philipp-Dormston, W.G., Prager, W., ..., \& Karrer, S. (2017). Daylight photodynamic therapy versus cryosurgery for the treatment and prophylaxis of actinic keratoses of the face - protocol of a multicenter, prospective, randomized, controlled, two-armed study. BMS Dermatol., 17, 29070025.

15. Dodds, A., Chia, A., \& Shumack, S. (2014). Actinic Keratosis: Rationale and Management. Dermatol. Ther. (Heidelb), 4, 1, 11-31.

16. Elizabeth, E. (2013). Uhlenhake optimal treatment of actinic keratoses. Clin. Interv. Aging, 8, 29-35.

17. Ash, C., Town, G., Whittall, R., Tooze, L., \& Phillips, J. (2017). Lasers and intense pulsed light (IPL) association with cancerous lesions. Lasers Med. Sci., 32, 8, 1927-1933.

\title{
ЭФФЕКТИВНОСТЬ КОМБИНИРОВАННОЙ ПОСЛЕДОВАТЕЛЬНОЙ ТЕРАПИИ АКТИНИЧЕСКОГО КЕРАТОЗА
}

\author{
○Т. В. Святенко ${ }^{1}$, В. С. Глушок', Т. С. Шкробот ${ }^{3}$ \\ ${ }^{1} Г У$ «Днепропетровская медицинская академия МЗ Украины» \\ ${ }^{2}$ Тернопольский национальный медицинский университет имени И. Я. Горбачевского мОз Украины \\ ${ }^{3}$ КНП «Тернопольский областной клинический кожно-венерологический диспансер»
}

РЕЗЮМЕ. Цель работы - оценить эффективность использования комбинированной последовательной терапии актинического кератоза (АК) путем сравнения с результатами терапевтической эффективности монотерапии.

Материал и методы. Разработан трехэтапный алгоритм комбинированной терапии, направленный на последовательное удаление участков атипичных пролифератов кератиноцитов, на снижение васкуляризации в имеющихся очагах АК и в возможных новых очагах на прилегающих участках кожи, а также на улучшение состояния фотоповрежденной кожи.

Под наблюдением находилось 90 пациентов с АК, рандомизированных в две группы. Пациенты первой группы (58 человек) получали комбинированную терапию согласно разработанной методике, пациентам 2-й группы (32 человека) была проведена только криодеструкция жидким азотом (методика монотерапии).

Результаты и выводы. На основе проведенного анализа жалоб и клинических данных пациентов до и после лечения доказано, что комбинированная терапия обеспечивает лучшие клинические и косметические эффекты, по сравнению с монотерапией. Высокая терапевтическая эффективность, хорошая переносимость, малоинвазивность процедур, доступность, удобство применения позволяют рекомендовать эту методику для лечения больных АК в Украине.

КЛючЕВЫЕ СЛОВА: актинический кератоз; IPL; криодеструкция; комбинированная терапия.

\section{EFFECTIVENESS OF COMBINED SEQUENTIAL THERAPY OF ACTINIC KERATOSIS}

\author{
@T. V. Svyatenko', V. S. Hlushok ${ }^{2}$, T. S. Shkrobot ${ }^{3}$ \\ ${ }^{1}$ Dnipropetrovsk Medical Academy \\ 2. Horbachevsky Ternopil National Medical University \\ ${ }^{3}$ Ternopil Regional Clinical Dermatovenerologic Dispensary
}

SUMMARY. The aim - to evaluate the effectiveness of the use of combination sequential therapy of actinic keratosis (AK), comparing it with the results of therapeutic effectiveness of monotherapy (liquid nitrogen cryodestruction).

Material and Methods. A three-stage combination therapy algorithm was developed to sequentially remove areas of atypical keratinocyte proliferates, to reduce vascularization in existing AK lesions, and in potentially possible new ones on adjacent skin areas, as well as to improve skin condition.

There were 90 patients with AK under observation. All patients were randomized into two groups. Patients of group 1 (58 persons) received the combination therapy according to the developed technique, patients of group 2 (32 persons) received only liquid nitrogen cryodestruction (monotherapy).

Results and Conclusions. According to the analysis of complaints and clinical data of patients before and after the treatment, it was proven that combination therapy provides the best clinical and cosmetic effects comparing with monotherapy. High therapeutic efficacy, good tolerability, minimally invasive procedures, accessibility, ease of use make it possible to recommend this technique for the treatment of AK patients in Ukraine.

KEY WORDS: actinic keratosis (AK); IPL; cryodestruction; combination therapy. 